\title{
A divergent population of Hemidactylus frenatus Duméril \& Bibron, 1836 (Reptilia: Gekkonidae) from the northern Eastern Ghats, India
}

\author{
S.M. Maqsood Javed ${ }^{1}$, C. Srinivasulu ${ }^{2}$, K. Lakshmi Rao ${ }^{3}$, T. Raseswari ${ }^{3} \&$ Farida Tampal ${ }^{4}$ \\ ${ }^{1,4}$ World Wide Fund for Nature-India (WWF), APSO, 818, Castle Hills, Road No. 2, Near NMDC, Vijayanagar Colony, Hyderabad, \\ Andhra Pradesh 500057, India \\ ${ }^{2}$ Wildlife Biology Section, Department of Zoology, University College of Science, Osmania University, Hyderabad, Andhra Pradesh, \\ 500007, India \\ ${ }^{3}$ Centre for Cellular and Molecular Biology (CCMB), Uppal Road, Hyderabad, Andhra Pradesh 500007, India \\ Email: ${ }^{1}$ javedwwf2007@gmail.com
}

Date of publication (online): 26 September 2010 Date of publication (print): 26 September 2010 ISSN $0974-7907$ (online) | 0974-7893 (print)

Editor: Aaron Bauer

\section{Manuscript details:}

Ms \# 02388

Received 18 January 2010

Final received 02 June 2010

Finally accepted 29 July 2010

Citation: Javed, S.M.M., C. Srinivasulu, K.L. Rao, T. Raseswari \& F. Tampal (2010). A divergent population of Hemidactylus frenatus Duméril \& Bibron, 1836 (Reptilia: Gekkonidae) from the northern Eastern Ghats, India. Journal of Threatened Taxa 2(10): 1205-1213.

Copyright: (C) S.M. Maqsood Javed, C. Srinivasulu, K. Lakshmi Rao, T. Raseswari \& Farida Tampal 2010. Creative Commons Attribution 3.0 Unported License. JoTT allows unrestricted use of this article in any medium for non-profit purposes, reproduction and distribution by providing adequate credit to the authors and the source of publication.

Author Details and Acknowledgements: see end of this article.

Author Contribution: SMMJ, CS and FT conducted the field surveys; SMMJ and CS identified and wrote the paper; KLR and TR performed chromosome analysis.
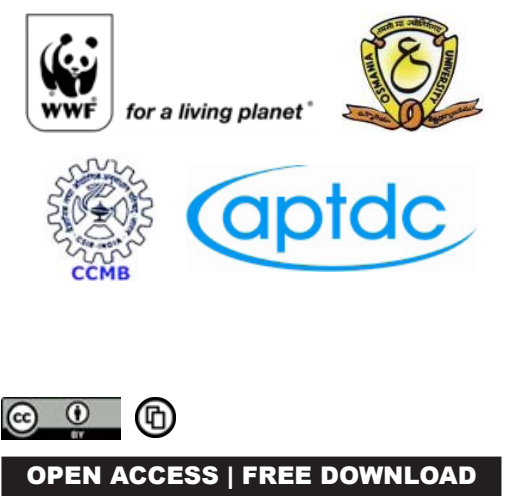

Abstract: A population of Hemidactylus cf. frenatus Duméril \& Bibron, 1836, was recorded from Tyda and its vicinity in the Ananthagiri Hills, northern Eastern Ghats, Vishakhapatnam District, Andhra Pradesh, India. Evaluation of morphometric and meristic characters supported by karyotyping revealed that populations from the Ananthagiri Hills are considerably different from other populations of $H$. frenatus occurring in India. We provide the detailed description of the male of this divergent population.

Keywords: Ananthagiri Hills, Andhra Pradesh, divergent population, Hemidactylus cf. frenatus, karyotype.

\section{INTRODUCTION}

The genus Hemidactylus Oken, 1817, belongs to the second most speciesrich lizard family in the world, Gekkonidae, with 100 species being described till date (Pough et al. 2000; Carranza \& Arnold 2005; Krysko \& Daniels 2005; McMahan \& Zug 2007; Giri 2008; Giri \& Bauer 2008; Giri et al. 2009; Mahony 2009; Uetz 2010). The genus Hemidactylus is distributed over large parts of tropical Asia, Africa, Mediterranean Europe and the Americas. It has been observed that a great majority of representatives of Hemidactylus geckos are restricted in distribution and confined to southern Asia and Africa, with only eight species namely $H$. brookii, $H$. bowringii, $H$. flaviviridis, $H$. frenatus, $H$. garnotii, $H$. persicus, $H$. mabouia and $H$. turcicus colonizing most of the geographical extent of this genus (Kluge 1969; Carranza \& Arnold 2005). In India, Hemidactylus is represented by 24 recognized species [validity of $H$. mahendrai and $H$. subtriedrus questioned by Zug et al. (2007) and as per Mahony \& Zug (2008) distribution of $H$. karenorum in India is doubtful] (Smith 1935; Sharma 1981; Shukla 1983; Bauer \& Russell 1995; Giri 2008; Giri \& Bauer 2008; Giri et al. 2009; Mahony 2009; Vyas et al. 2006). Recently, four species, namely, Hemidactylus aaronbaueri Giri, 2008; Hemidactylus gujaratensis Giri et al., 2009; Hemidactylus sataraensis Giri \& Bauer, 2008; Hemidactylus treutleri Mahony, 2009 were described from India (two species from Maharashtra and one species each from Gujarat and Andhra Pradesh). From the state of Andhra Pradesh alone 11 species represent the genus Hemidactylus (Murthy 1986; Rao et al. 2005; Srinivasulu \& Das 2008; Mahony 2009).

While conducting faunistic surveys in Tyda $\left(18^{\circ} 13^{\prime} \mathrm{N} \& 83^{\circ} 02^{\prime} \mathrm{E}\right)$ (Image 1), which is a part of the Ananthagiri Hills, northern Eastern Ghats of Andhra Pradesh, we came across a population of Hemidactylus cf. frenatus. A detailed examination of the external morphology revealed disagreement with some characters between this population and those often referred to $H$. frenatus in 
India. In the present paper we report the discovery of a morphologically and chromosomally divergent population of the $H$. frenatus species complex from the northern Eastern Ghats, Andhra Pradesh, India.

Natural History: Tyda is a well known tourist destination in the Ananthagiri Hills, Andhra Pradesh (Image 1). Hemidactylus cf. frenatus specimens were collected from a shelter room and a kiosk in front of the Tyda railway station (Image 2). We also observed that this species is wide spread throughout the Ananthagiri Hills. Mostly, it is active during the night, but on a number of occasions we sighted individuals on tree trunks (Mangifera indica, Tamarindus indica and Tectona grandis) at 3-5 m height during the day. Generally this gecko is commensal and found on walls near artificial lighting in groups of 3-5 individuals and in August 2009 we also recorded 2-5 juveniles along with them. Gravid females were recorded in February and July and possessed two eggs (Image 5 \& 6). Populations of the taxon were found sympatrically with $H$. brookii, H. leschenaultii and Hemidactylus cf. maculatus.

\section{MATERIALS \& METHODS}

A specimen of gecko encountered near Tyda Railway Station was collected and photographed. Another three specimens were collected from different places in Tyda, Araku and Ananthagiri. Further surveys revealed this species to be common among the human dwellings in the study area. After extracting tissue for karyotyping from two males, all four specimens (ZSI/FBRC/V-1521-1524) ( 3 males and 1 female) were euthanized, fixed in 10\% formalin, preserved in $70 \%$ alcohol and deposited in

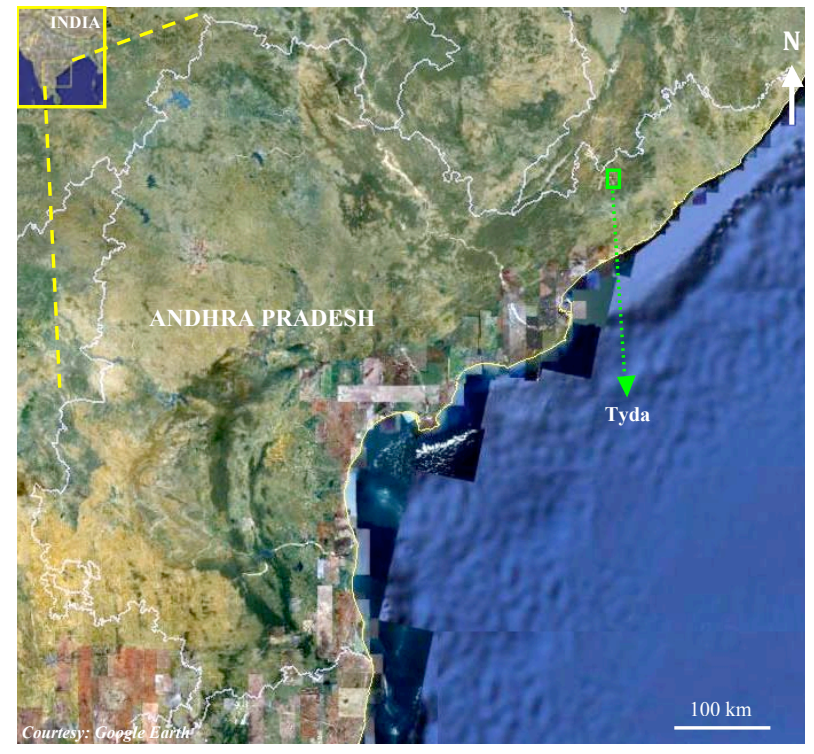

Image 1. Satellite image showing map depicting collection site of Hemidactylus cf. frenatus.

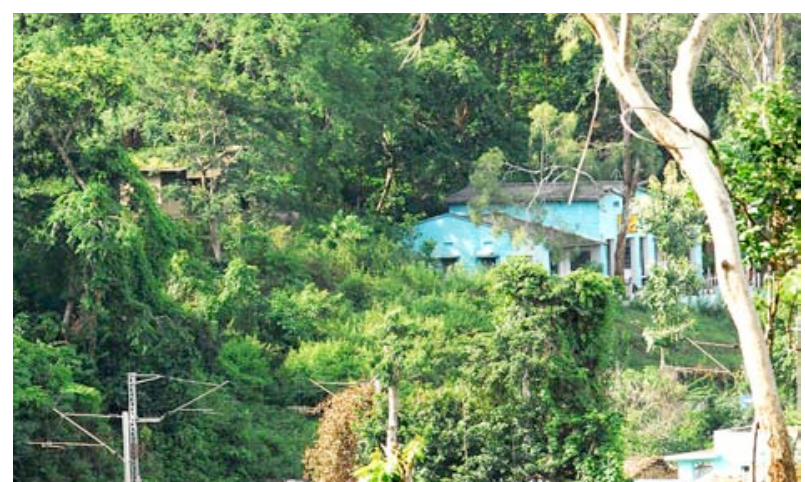

Image 2. Tyda railway station, one of the collection sites of Hemidactylus cf. frenatus.
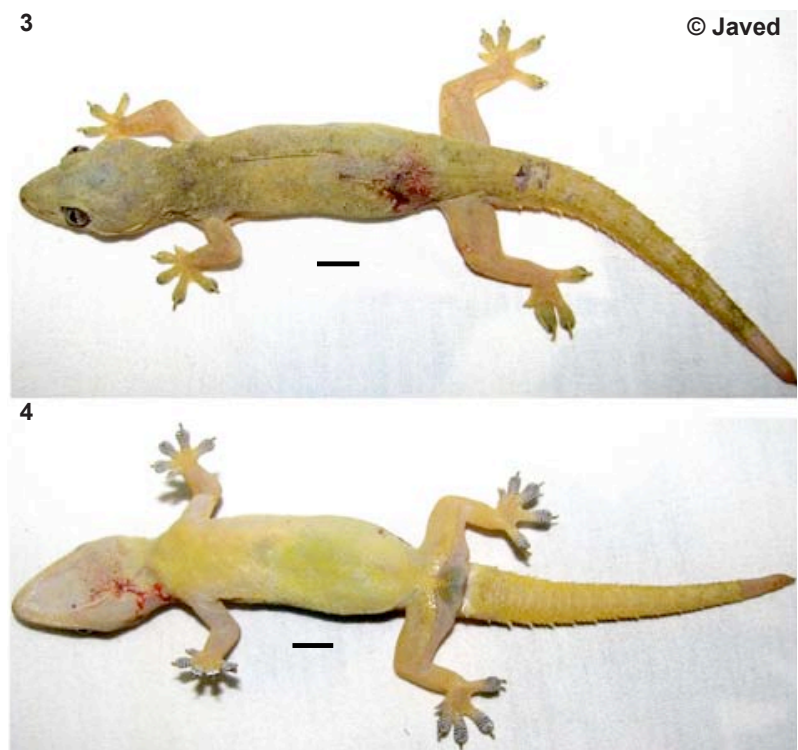

Images 3 \& 4. Hemidactylus cf. frenatus male (ZSI/

FBRC/V-1521) (live). 3 - Dorsal aspect; 4 - Ventral aspect. Note: The bloody area infected by an unknown parasite. (Scale $=5 \mathrm{~mm})$.

the collection of the Zoological Survey of India, Freshwater Biology Regional Center, Vertebrate section (ZSI/FBRC/V), Hyderabad. Photo vouchers (PV) are deposited in the Natural History Museum, Osmania University, Reptilia section, Hyderabad (NHM.OU.REP). Specimens were identified based on the descriptions and keys available in the literature (Jerdon 1853; Boulenger 1890; Rooij 1915; Smith 1935; Loveridge 1947; Kluge \& Eckardt 1969; Darevsky et al. 1984; Wells \& Wellington 1985; Ota 1989; Ota \& Hikida 1989; Sharma 2002; Wells 2002; Giri et al. 2003; Giri \& Bauer 2006; McMahan \& Zug 2007; Zug et al. 2007; Giri 2008; Giri \& Bauer 2008; Mahony 2009). Karyotyping was done following Ota \& Hikida (1989) and Rao \& Aswathanarayana (1979) in the Centre for Cellular and Molecular Biology (CCMB), Hyderabad. Each animal was injected intraperitoneally with colcemid. After approximately $2 \mathrm{hr}$ the animal was 

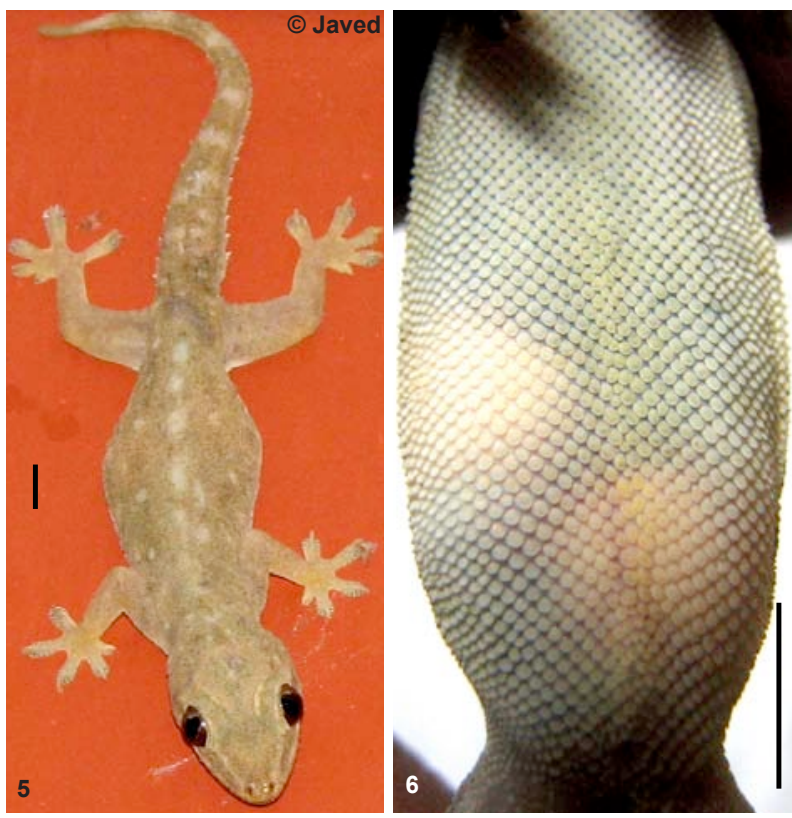

Images 5 \& 6. Hemidactylus cf. frenatus female (ZSI/ FBRC/V-1522) (live). 5 - Dorsal aspect; 6 - Ventral aspect, showing abdomen bearing eggs. (Scale $=5 \mathrm{~mm}$ ).

sacrificed. Bone marrow from the femur and tibia was aspirated and suspended in hypotonic solution for 45 $\min$ at $28^{\circ} \mathrm{C}$. Cells were then fixed with acetic alcohol: methanol (1:3) and centrifuged. The cells were refixed with fresh fixative for 30 minutes, dried on slides, and stained with Giemsa. Comparative material was examined at the Zoological Survey of India, Kolkata (ZSIK) by the second author.

Morphological and meristic studies were conducted in the Department of Zoology, Osmania University, Hyderabad. All measurements were taken following Zug et al. (2007) and Giri \& Bauer (2008) with Mitutoyo digital calipers (to the nearest $0.1 \mathrm{~mm}$ ): snout-vent length (SVL; from tip of snout to vent), trunk length (TRL; distance from axilla to groin measured from posterior edge of forelimb insertion to anterior edge of hind limb insertion), body width (BW; maximum width of body), crus length (CL; from base of heel to knee); tail length (TL; from vent to tip of tail), tail width (TW; measured at widest point of tail); head length (HL; distance between retroarticular process of jaw and snout-tip), head width (HW; maximum width of head), head height $(\mathrm{HH}$; maximum height of head, from occiput to underside of jaws), forearm length (FL; from base of palm to elbow); orbital diameter (OD; greatest diameter of orbit), nares to eye distance (NE; distance between anteriormost point of eye and nostril), snout to eye distance (SE; distance between anterior most point of eye and tip of snout), eye to ear distance (EE; distance from anterior edge of ear opening to posterior corner of eye), internarial distance (IN; distance between nares), interorbital distance (IO; distance between left and right supraciliary recorded at the center). Meristic counts and
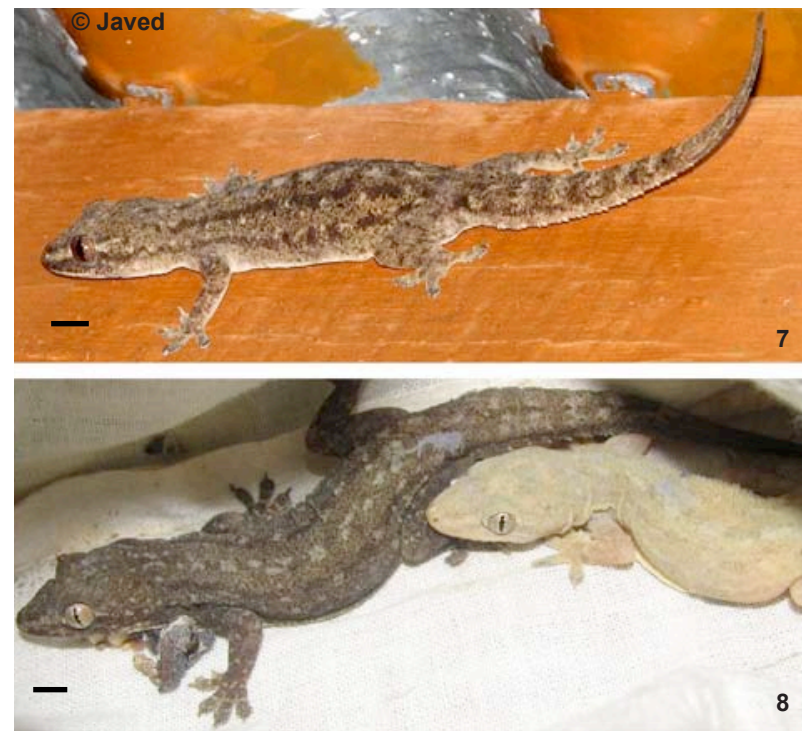

Images 7 \& 8. Hemidactylus cf. frenatus males (live). 7 - Dorsal aspect (NHM.OU.REP.PV.7-2009), showing colour pattern; 8 - Dorsal aspect (ZSI/FBRC/V-1523 \&1524), showing different colour contrasts indicating changes in body colour due to physiological stress. (Scale $=5 \mathrm{~mm}$ )

external observations of morphology were made using a dissecting microscope.

\section{RESULTS}

\section{Reptilia: Squamata: Gekkonidae Hemidactylus cf. frenatus}

Material Examined: 1 male (ZSI/FBRC/V-1521) and 1 female (ZSI/FBRC/V-1522), 8.xii.2009, 18 ${ }^{\circ} 13^{\prime} \mathrm{N}$ \& 8302'E, Tyda; 1 male (ZSI/FBRC/V-1523),10.xii.2009, $18^{\circ} 14^{\prime} \mathrm{N} \& 8^{\circ} 00^{\prime} \mathrm{E}$, Ananthagiri Village; 1 male (ZSI/ FBRC/V-1524),12.xii.2009, 18019'N \& 82052'E, Araku Town, Vishakhapatnam District, Andhra Pradesh, India, coll. S. Aatram \& C. Ramana.

Other sources: Photo vouchers deposited at the Natural History Museum, Osmania University. Three photo vouchers (male/female/female: NHM.OU.REP. PV.7/8/9-2009), locality details same as above; 1 photo voucher (female: NHM.OU.REP.PV.10-2009), H. frenatus, Hyderabad, Andhra Pradesh.

\section{Description of Hemidactylus cf. frenatus from northern Eastern Ghats, Andhra Pradesh}

The Hemidactylus cf. frenatus population from Tyda is distinguished from all the other populations of $H$. frenatus reported from India by the following suite of characters: maximum 13 supralabials ( $v s$. maximum 12 supralabials); dual set of outer postmentals separated by two scales in a longitudinal row from infralabials or rarely in contact ( $v s$. outer postmentals always in contact with infralabials); a maximum of six scansors beneath digit I of pes (vs. a 


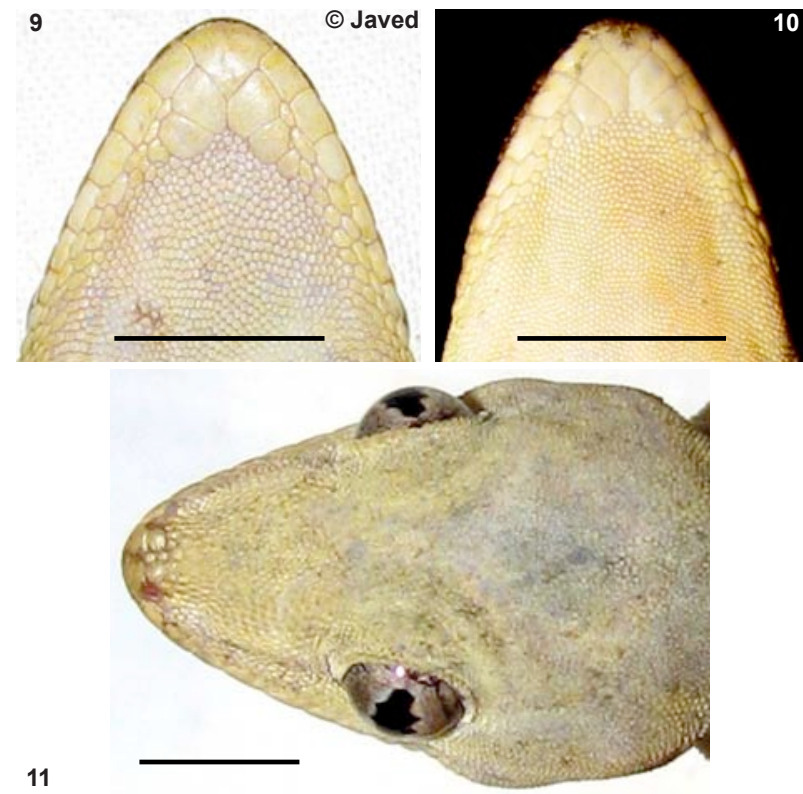

Images 9-11. Hemidactylus cf. frenatus (live). 9 - Ventral aspect, male (ZSI/FBRC/V-1521) head region showing secondary postmentals separated from infralabials; 10 - Ventral aspect, female (NHM.OU.REP.PV.82009) (live) head region showing secondary postmentals in contact with infralabials; 11 - Dorsal aspect, male (ZSI/ FBRC/V-1521) (live) showing snout and forehead. $($ Scale $=5 \mathrm{~mm})$

maximum of 5 scansors); 10-17 femoral pores on each side separated at mid-pelvic region by 3-4 non-pored scales [vs. continuous series of 23-36 femoral pores, or separated at mid-pelvic region by 1-2 non-pored scales (1-2 non-pored scales only reported from Myanmar populations $H$. frenatus) (Smith 1935; Zug et al. 2007)] (Images 15, 15a, 19 \& 20); conspicuous ventrolateral body fold present on trunk and thigh (vs. no ventrolateral body folds present on trunk and thigh) (Image 8); all digits of manus and pes distinctly webbed at the base (vs. slightly webbed or no webbing at the base); distal end of digital pads much wider than proximal end (vs. distal end of digital pads slightly wider than proximal end); tail moderately denticulate at lateral edge (vs. not denticulate at lateral edge).

Description of Male (ZSI/FBRC/V-1521): A medium sized gecko (SVL $60.9 \mathrm{~mm}$ ). Head relatively short and robust (HL/SVL ratio 0.22), with distinct broadening at position of jaw angles (HW/HL ratio 0.86$)$, without snout elongation (SE/HW ratio 0.58) and overall depression $(\mathrm{HH} /$ $\mathrm{HL}$ ratio 0.53 ). Loreal region and canthus rostralis slightly inflated. Interorbital and forehead region slightly concave; snout obtusely pointed; longer than eye diameter (OD/SE ratio 0.54 ); scales on snout and forehead large, rounded, granular and juxtaposed; scales on snout larger than those on occipital region; small scales on occipital region intermixed with larger, smooth granular scales (Images 11 \& 12) . Interorbital scales between supraciliaries $\sim 51$.

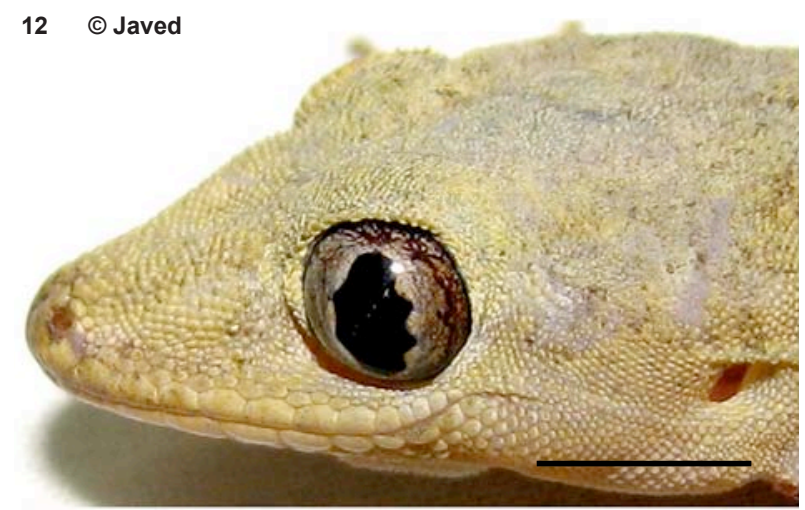

13

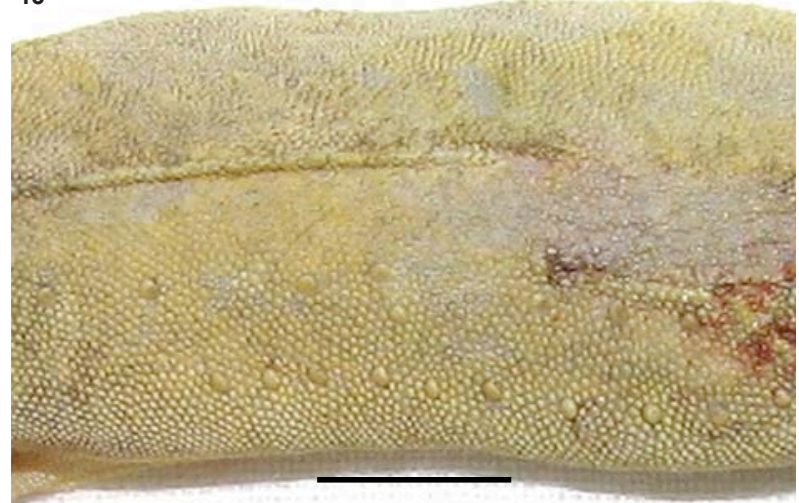

Image 12 \& 13. Hemidactylus cf. frenatus male (ZSI/ FBRC/V-1521) (live). 12 - Dorsolateral aspect, head region showing eye, ear opening and labials; 13 - Dorsolateral aspect, trunk region showing round scales. (Scale $=5 \mathrm{~mm}$ )

Eyes large (OD/HL ratio 0.27); pupil vertical and broad with crenulated margin; supraciliaries small, pointed, those at the anterior end of orbit slightly larger; ear-opening deep, oval, vertical and large, ears lacking lobules; eye to ear distance greater than diameter of eye (EE/OD ratio 1.39) (Image 12). Rostral scale quadrangular, much wider $(2.2 \mathrm{~mm})$ than deep $(1.1 \mathrm{~mm})$, slightly notched by suture dorsomedially, in contact with nostril, first supralabial and supranasal; supranasals separated by two scales in a longitudinal row (Image 11); nostril circular, in contact with rostral, one enlarged supranasal, two postnasals, of which the posterior is larger; mental triangular, larger than postmentals; two pairs of postmentals, primary pair larger, in contact with each other, mental, infralabials and secondary postmental; secondary postmental pair small, separated and half the size of the primary postmentals, lying posterior to the primary postmentals and separated from infralabials by single row of scales (Image 9); orbit separated from supralabials by three scale rows; supralabials (to midorbital position) 8 (right)/8 (left) and supralabials (to angle of jaw) 13 (right)/13 (left); infralabials (to angle of jaw) 10 (right)/10 (left) (Image 12).

Body moderately elongated (TRL/SVL ratio 0.51 ) (Image 3), dorsoventrally flattened with conspicuous ventrolateral furrow. Dorsal scales small, granular, 


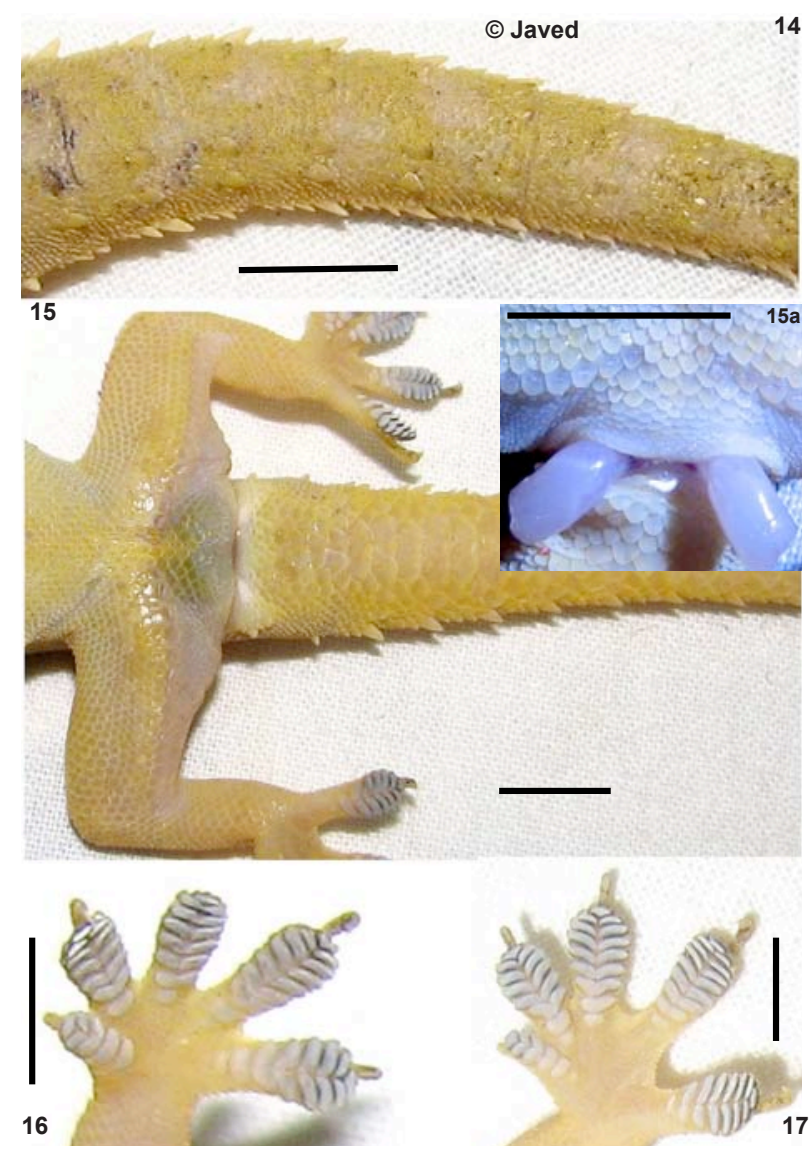

Images 14 - 17. Hemidactylus cf. frenatus male (live) (ZSI/ FBRC/V-1521). 14 - Dorsal aspect of tail; 15- Ventral aspect groin region and tail; 15a - Male (ZSI/FBRC/V-1523) (live) partly everted hemipennis and four non-pored median scales separating precloacal-femoral pore rows of left and right sides; 16-17 - Ventral aspect of the manus (16) and pes (17). (Scale $=5 \mathrm{~mm}$ )

heterogeneous, juxtaposed, intermixed with regularly arranged, relatively large, round, smooth tubercles arranged in a longitudinal rows on the dorsolateral region, extending from the middle of the trunk (Image 13) to the base of tail; scales more or less uniform across dorsum and flanks; mid body scales around trunk 96 . Ventral scales much larger than dorsals, smooth, flat, roundish lozenge-shaped, a bit larger on mid-abdomen than near axilla and groin; mid body scales across belly $~ 44$; gular region with much smaller, uniform and granular scales. Femoral pores 14 on each side, separated at mid-pelvic region by three non-pored scales (Image 15). Distinct, but slight cutaneous folds present on the posterior border of hind limbs. Manus and pes possess large, smooth and flat scales on the dorsal region, while ventrolateral region possess small, smooth and flat scales. Posterior half of the thigh on ventral side (posterior to femoral pore row) possesses very small, smooth and granular scales.

Limbs moderately long; digits long, moderately dilated, bearing scansors and clawed; forelimbs slender and short

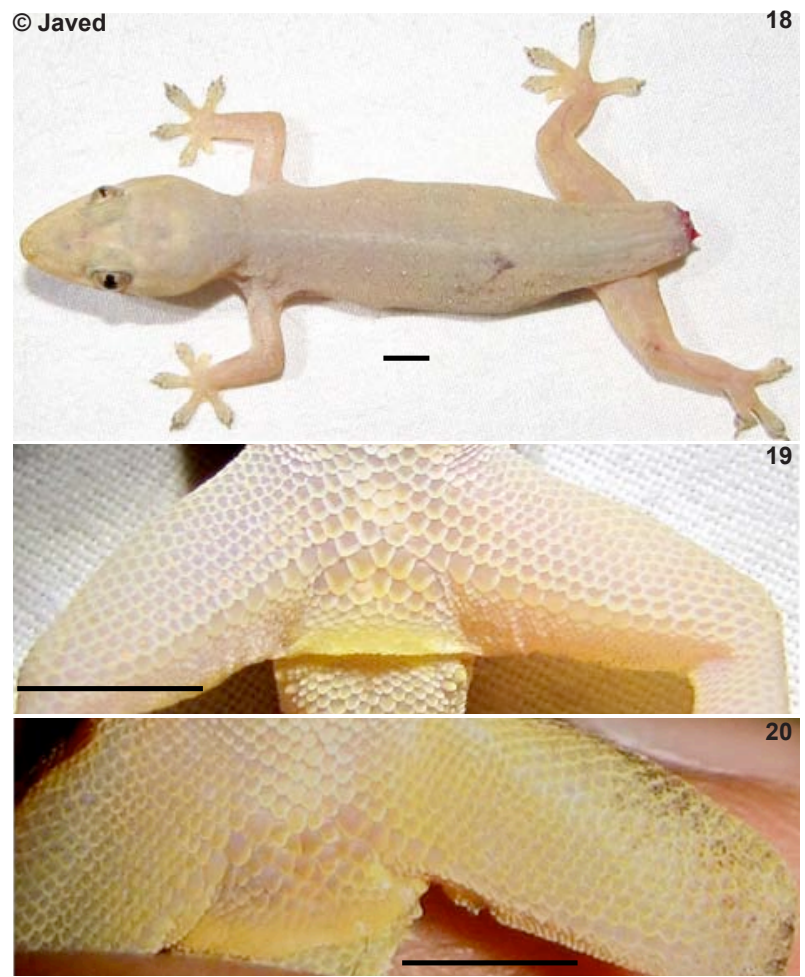

Images 18 \& 19. Hemidactylus cf. frenatus female (NHM. OU.REP.PV.10-2009) (live). 18 - Dorsal aspect, showing elongated body with thin digits; 19 - Ventral aspect, cloacal region and base of tail, showing enlarged precloacalfemoral scales arranged continuously and relatively enlarged precloacal scales. (Scale $=5 \mathrm{~mm})$.

Image 20 - Hemidactylus cf. frenatus female (NHM.OU.REP. PV.9-2009) (live) ventral aspect, cloacal region showing four non-pore scales separating enlarged femoral scales and bottom of thigh with conspicuous fold. (Scale $=5 \mathrm{~mm}$ ).

(FL/SVL ratio 0.12) in comparison with hindlimbs (CL/SVL ratio 0.15$)$; all digits of manus and pes indistinctly webbed at the base (Images $16 \& 17$ ), terminal phalanx of all digits curved, arising angularly from distal portion of expanded lamellar pad. Scansors beneath digits I-V of manus (undivided + deeply notched or divided + entire apical) (right/left): $5(2+3+1) / 5(2+3+1), 7(1+5+1) / 7(1+5+1)$, $8(2+5+1) / 8(2+5+1), 9(2+6+1) / 9(2+6+1), 8(3+4+1) / 8$ $(3+4+1)$; beneath digits I-V of pes (right/left): $6(2+3+1) / 6$ $(3+2+1), 8(2+5+1) / 8(2+5+1), 9(2+6+1) / 9(2+6+1), 10$ $(3+7+1) / 10(3+7+1), 8(2+5+1) / 8(2+5+1)$ (Image 16 \& 17). Relative length of digits (measurements in $\mathrm{mm}$ in parentheses): IV (3.8) > V (3.1) > III (3.4) > II (3.3) > I (1.6) (right manus); IV (5.1) > V (5) > III (3.6) > II (3.4) > I (1.8) (right pes).

Tail moderately depressed, oval in cross section, relatively short, original portion $35.9 \mathrm{~mm}$, regenerated from $14^{\text {th }}$ segment (terminal $12 \mathrm{~mm}$ regenerated); postcloacal hemipeneal bulge indistinct; two small postcloacal spurs present, posterior larger than anterior; regenerated portion of tail with uniform, smooth, flattened dorsal scales. Original 
Table 1. Morphometric and meristic data on Hemidactylus cf. frenatus from Tyda, Ananthagiri and Araku in Ananthagiri Hills, northern Eastern Ghats, Andhra Pradesh (all morphometric measurements in $\mathrm{mm}$ ).

\begin{tabular}{|c|c|c|c|c|}
\hline Character & $\begin{array}{c}\text { ZSI/FBRC/V-1521 } \\
\text { (Male) }\end{array}$ & $\begin{array}{c}\text { ZSI/FBRC/V-1522 } \\
\text { (Female) }\end{array}$ & $\begin{array}{c}\text { ZSI/FBRC/V-1523 } \\
\text { (Male) }\end{array}$ & $\begin{array}{c}\text { ZSI/FBRC/V-1524 } \\
\text { (Male) }\end{array}$ \\
\hline SVL & 60.9 & 56 & 44.3 & 62 \\
\hline TRL & 31.4 & 29.6 & 21.1 & 33.9 \\
\hline BW & 11 & 12.3 & 9 & 14.7 \\
\hline $\mathrm{CL}$ & 9.7 & 8.81 & 6.29 & 8.70 \\
\hline $\mathrm{TL}$ & 47.9 & 52.1 & 44.2 & 54.9 \\
\hline TW & 6.8 & 6.5 & 5.1 & 7.6 \\
\hline $\mathrm{HL}$ & 13.9 & 11.3 & 9.6 & 13.9 \\
\hline HW & 12 & 10.3 & 9 & 12.4 \\
\hline $\mathrm{HH}$ & 7.5 & 6.4 & 4.9 & 7.5 \\
\hline $\mathrm{FL}$ & 7.5 & 6.6 & 5.9 & 7 \\
\hline OD & 3.8 & 3.6 & 2.9 & 4 \\
\hline NE & 6.3 & 5.5 & 4.5 & 5.9 \\
\hline SE & 7 & 6.9 & 5.5 & 7.1 \\
\hline EE & 5.3 & 4.8 & 3.9 & 5.3 \\
\hline $\mathrm{IN}$ & 1.8 & 1.6 & 1.5 & 1.4 \\
\hline 10 & 5.8 & 6.8 & 4.7 & 6.9 \\
\hline \multicolumn{5}{|c|}{ Scansors (right/left): } \\
\hline Digit I manus & $5 / 5$ & $5 / 5$ & $5 / 5$ & $5 / 5$ \\
\hline Digit IV manus & $9 / 9$ & $9 / 9$ & $9 / 9$ & $9 / 9$ \\
\hline Digit I pes & $6 / 6$ & $5 / 5$ & $6 / 6$ & $6 / 6$ \\
\hline Digit IV pes & $10 / 10$ & 9/9 & $10 / 10$ & $10 / 10$ \\
\hline \multicolumn{5}{|l|}{ Labials (right/left): } \\
\hline Supralabials & $13 / 13$ & $13 / 12$ & $13 / 13$ & $13 / 13$ \\
\hline Infralabials & $10 / 10$ & $10 / 10$ & $10 / 10$ & $10 / 10$ \\
\hline
\end{tabular}

tail bears fourteen caudal segments; caudal segmentation distinct, possesses 9-11 rows of small, granular, slightly overlapping heterogeneous scales intermingled with six large, smooth, pointed scales arranged transversely (Image 14) and slanting posteriorly on the dorsum of each segment; median subcaudal series possesses smooth scales, transversely enlarged and each much wider than long; scales on postcloacal region and at proximal part of tail base slightly overlapping, larger than dorsal scales on tail (Image 15); lateral edge of tail distinctly denticulate, each caudal bearing a single, large, pointed, conical scale near the posterior margin and, anterior to this, three small, pointed, conical scales on original portion (size of scales gradually decreases anteriorly) (Image 14) and no such serration on regenerated portion.

Colouration: In life, dorsum yellowish-gray, slightly darker on distal half of digits; indistinct light spots white or creamy white in colour on body and limbs; venter of head, body, original portion of tail, and most of limbs lemon yellow; subdigital regions and regenerated portion of tail light yellowish-brown (Images 3 \& 4). In alcohol, dark gray colour pattern on dorsum and lemon yellow colour on ventral completely faded; numerous irregular black pigment spots present on almost every scale of the body, limbs and tail.

Variation: All other specimens (Images 5, 7 \& 8) observed differed significantly from the described male only in colouration in life and placement of enlarged tubercles arranged in longitudinal rows on the dorsolateral region. One specimen (ZSI/FBRC/V-1523) has 12 supralabials on the right side and two enlarged scales between the secondary postmentals. The number of femoral pores on each side and general morphometry also varied (Table 1). Thirty-two individuals were examined during the survey, of which six were recorded as possessing secondary postmentals in contact with the infralabials (Image 10). The range of femoral pores in adult males on each side 10-17, separated at mid-pelvic region by 3-4 non-pored scales (Images $15 \& 15 a)$. No femoral pores are present in females (Image 20) and two postcloacal spurs are present in both the sexes, but more prominent in males. 


\section{Karyotype}

Two male specimens were used for karyotyping and no variation was observed. Based on 12 well spread metaphasecells, the karyotype of Hemidactylus cf. frenatus from Tyda consists of 40 chromosomes of different sizes (Image 21). There were no sharp differences between macrochromosomes and microchromosomes. No heteromorphic chromosome pairs were recognized. The karyotype (Image 22) is arranged in pairs mainly on the basis of varying sizes noted in the captured metaphases. All chromosomes have acrocentric appearance (Ashaped rods graded to dots) and among them 2 were large in size, 18 medium and 20 small. Other species of the genus Hemidactylus $(H$. brookii, $H$. frenatus and $H$. flaviviridis) also have this same number of chromosomes, but differs from those of Hemidactylus cf. frenatus in size and morphology $[H$. brookii $=4 \mathrm{~V}$ (metacentric) + $36 \mathrm{~A}$ (acrocentric rods graded to dots), $H$. frenatus $=2 \mathrm{~V}$ (metacentric) + 4SV (submetacentric) + 34A (acrocentric: probably $26 \mathrm{~A}+2 \mathrm{~V}+6 \mathrm{SV}$ ) rods graded to dots and $H$. flaviviridis $=2 \mathrm{~V}$ (metacentric) + 4SV (submetacentric) + $34 \mathrm{~A}$ (acrocentric: probably $26 \mathrm{~A}+2 \mathrm{~V}+6 \mathrm{SV}$ ) rods graded to dots] (Kluge \& Eckardt 1969, Darevsky et al. 1984; Ota \& Hikida 1989). Along with this, on the basis of chromosome number, $H$. bowringii $(2 n=46), H$. garnotii $(2 n=3 x=$ $42 ; 2 n=3 x=63 ; 2 n=3 x=70), H$. flaviviridis $(2 n=46)$ and even some populations of $H$. frenatus $\left(2 n=46^{\star}\right.$ in error; $2 n=3 x=60$ ) (Das \& Ota 1998) are considerably differentiated from the population of Hemidactylus cf. frenatus from Tyda. Details of chromosome numbers of Hemidactylus species found in India (derived from Das \& Ota 1998) are provided in Table 2.

\section{Distribution}

At present this population of Hemidactylus cf. frenatus is only known from the Tyda and its surroundings (Araku and Ananthagiri) in the northern Eastern Ghats, Andhra Pradesh, India.

\section{DISCUSSION}

The Common House Gecko, $H$. frenatus is native to South and Southeast Asia, and the Indo-Australian Archipelago, but has since been widely introduced throughout many tropical and subtropical regions (Bauer \& Henle 1994). Its range currently includes countries in eastern Africa, Madagascar, many of the islands of the South Pacific, Hawaii, Mexico, central America, and the United States (Rooij 1915; Bauer \& Henle 1994; Case et al. 1994; Vences et al. 2004). Recent molecular phylogeny studies for genus Hemidactylus (Carranza \& Arnold 2005) revealed that $H$. frenatus belongs to Tropical Asian clade and one southern Indian population of $H$. frenatus shows high genetic variability (10\% divergence) from Myanmar. This discovery of a morphologically

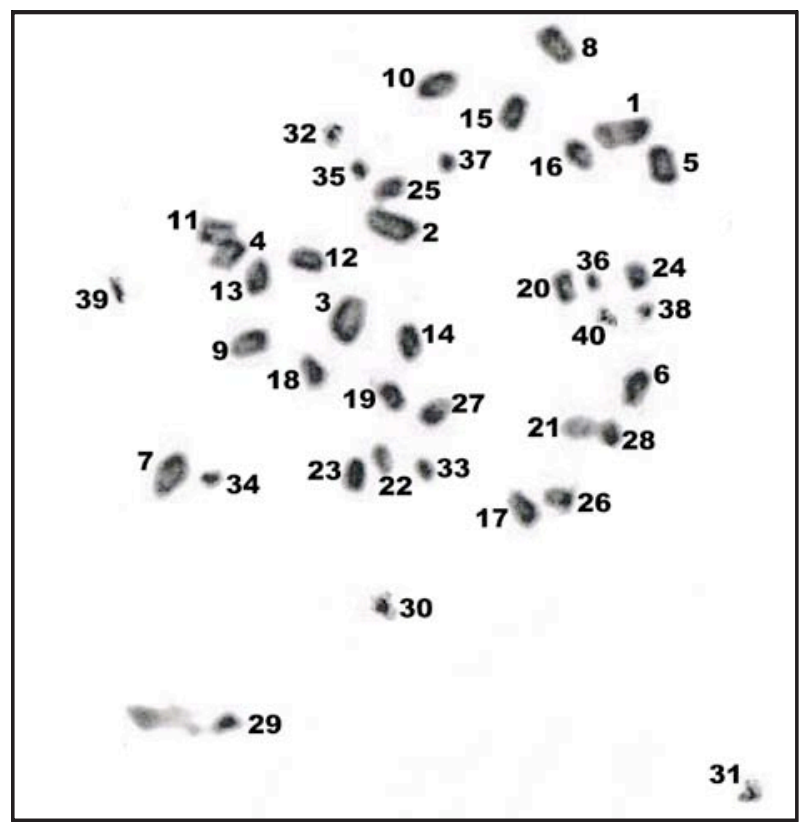

Image 21. A photograph of a metaphase $(2 n=40)$ of a bone marrow cell from Hemidactylus cf. frenatus male (ZSI/ FBRC/V-1524). Magnification: 1000X.

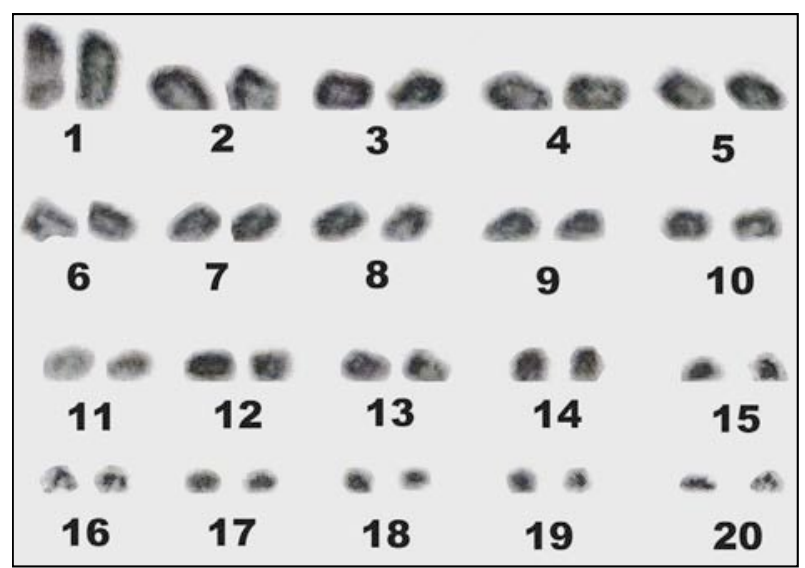

Image 22. A karyotype of Hemidactylus cf. frenatus male (ZSI/FBRC/V-1524) showing all acrocentric $2 n=40$ chromosomes of different sizes.

divergent population from Ananthagiri Hills probably reflects genetic differentiation, as was also shown by the karyotypic data [ $2 n=40$ chromosomes (all acrocentric)]. Further investigation with the help of DNA sequence data may be useful in differentiating hidden lineages in this cryptic species complex.

\section{REFERENCES}

Bauer, A.M. \& A.P. Russell (1995). The systematic relationships of Dravidogecko anamallensis (Günther, 1875). Asiatic Herpetological Research 6: 30-35.

Bauer, A.M. \& K. Henle (1994). Gekkonidae (Reptilia, Sauria). 
Table 2. Chromosome numbers of Hemidactylus species found in India

\begin{tabular}{|c|c|c|}
\hline & Species & Karyotype with references sourced from Das \& Ota (1998) \\
\hline 1 & H. bowringii (Gray, 1845) & 2n = 46 (Nakamura 1931 \& 1932 from Taiwan; Ota et al. 1989 from Ryukyu Archipelago, Japan). \\
\hline 2 & H. brookii Gray, 1845 & $2 n=40$ (Bhatnagar 1962 from India). \\
\hline 3 & $\begin{array}{l}\text { H. flaviviridis Duméril \& Bibron, } \\
1836\end{array}$ & $\begin{array}{l}\text { 2n = } 40 \text { (Branch } 1980 \text { from Oman; Singh, 1974b; Singh \& Bhatnagar } 1987 \text { from India) and 2n = } 46 \\
\text { (Asana \& Mahanale } 1941 \text { from India; Makino \& Momma 1949). }\end{array}$ \\
\hline 4 & H. frenatus Duméril \& Bibron, 1836 & $\begin{array}{l}2 n=46 \text { (*Makino \& Momma 1949), } 2 n=40 \text { (King } 1978 \text { from northern Australia; Darevesky et al. } \\
1984 \text { from Vietnam; Kupriyanova et al. } 1989 \text { from Taiwan and the Ryukyu Archipelago, Japan; Ota } \\
\text { et al. } 1989 \text { from Malaysia \& Mariana) and } 2 n=3 x=60 \text { (Moritz \& King } 1985 \text { from Oceania). } \\
{ }^{*} \text { Remarks: The } 2 n=46 \text { Karyotype reported by Makino \& Momma (1949) is considered to be in error } \\
\text { by Kupriyanova et al. (1989). }\end{array}$ \\
\hline 5 & H. garnotii Duméril \& Bibron, 1836 & $\begin{array}{l}2 n=3 x=63 \text { (Moritz et al. } 1993 \text { from French Polynesia; Ota et al. } 1995 \text { from Hong Kong, eastern } \\
\text { China), } 2 n=3 x=42 \text { (Ota et al. 1996a from Thailand) and } 2 n=3 x=70 \text { (Kluge \& Eckardt } 1969 \text { from } \\
\text { Hawaii \& Florida, USA). }\end{array}$ \\
\hline 6 & Hemidactylus cf. frenatus & $2 n=40$ (This paper). \\
\hline
\end{tabular}

Part 1: Australia and Oceania. Das Tierreich 109, 306pp.

Boulenger, G.A. (1890). The Fauna of British India, Including Ceylon and Burma. Reptilia and Batrachia. Taylor \& Francis, London, xviii+541pp.

Carranza, S. \& E.N. Arnold (2006). Systematics, biogeography, and evolution of Hemidactylus geckos (Reptilia: Gekkonidae) elucidated using mitochondrial DNA sequences. Molecular Phylogenetics and Evolution 38: 531-545.

Case, T.J., Bolger, D.T. \& K. Petren (1994). Invasions and competitive displacement among house geckos in the tropical Pacific. Ecology 75(2): 464-477.

Das, I. \& H. Ota (1998). A checklist of chromosome numbers of South Asian reptiles. Hamadryad 23(2): 179-193.

Darevsky, I.S., Kupriyanova, L.A. \& V.V. Roshchin (1984). A new all-female triploid species of gecko and karyological data on the bisexual Hemidactylus frenatus from Vietnam. Journal of Herpetology 18: 277-284.

Giri, V.B. (2008). A new rock dwelling Hemidactylus (Squamata: Gekkonidae) from Maharashtra, India. Hamadryad 32: 2533.

Giri, V B. \& A.M. Bauer (2006). Notes on the distribution, natural history and variation of Hemidactylus prashadi Smith, 1935 Hamadryad 30(1-2): 55-60.

Giri, V.B. \& A.M. Bauer (2008). A new ground-dwelling Hemidactylus (Squamata: Gekkonidae) from Maharashtra, with a key to the Hemidactylus of India. Zootaxa 1700: 2134.

Giri, V.B., A.M. Bauer \& N. Chaturvedi (2003). Notes on the distribution, natural history and variation of Hemidactylus giganteus Stoliczka, 1871. Hamadryad 27(2): 217-221.

Giri, V.B., A.M. Bauer, R. Vyas \& S. Patil (2009). New species of rock-dwelling Hemidactylus (Squamata: Gekkonidae) from Gujarat, India. Journal of Herpetology 43(3): 385-393.

Jerdon, T.C. (1853). Catalogue of the reptiles inhabiting the peninsula of India. Part 1. Journal of the Asiatic Society of Bengal 22[1853]: 462-479.

Kluge, A.G. (1969). The evolution and geographic origin of the new world Hemidactylus mabouia-brookii complex (Gekkonidae, Sauria). Miscellaneous Publications Museum of Zoology University of Michigan 138: 1-78.

Kluge, A.G. \& M.J. Eckardt (1969). Hemidactylus garnotii Duméril and Bibron, a triploid all-female species of gekkonid lizard. Copeia 1969: 651-664.

Krysko, K.L. \& K.J. Daniels (2005). A key to the geckos (Sauria: Gekkonidae) of Florida. Caribbean Journal of Science 41(1) 28-36.

Loveridge, A. (1947). Revision of the African lizards of the family Gekkonidae. Bulletin of the Museum of Comparative Zoology
98: $1-469$

McMahan, C.D. \& G.R. Zug (2007). Burmese Hemidactylus (Reptilia, Squamata, Gekkonidae): geographic variation in the morphology of Hemidactylus bowringii in Myanmar and Yunnan. Proceedings of the California Academy of Sciences 58(24): 485-509.

Mahony, S. (2009). A new species of gecko of the genus Hemidactylus (Reptilia: Gekkonidae) from Andhra Pradesh, India. Russian Journal of Herpetology 16(1): 27-34.

Mahony, S. \& G.R. Zug (2008). Hemidactylus karenorum (Squamata, Gekkonidae) in India. Hamadryad 32: 84-86.

Murthy, T.S.N. (1986). Lizards of Kurnool district. Bulletin of the Maryland Herpetological Society 22(3): 134-143.

Ota, H. (1989). Hemidactylus okinawensis Okada, 1936, a junior synonym of $H$. frenatus Duméril \& Bibron, 1836. Journal of Herpetology 23(4): 444-445.

Ota, H. \& T. Hikida (1989). A new triploid Hemidactylus (Gekkonidae: Sauria) from Taiwan, with comments on morphological and karyological variation in the $H$. garnotiivietnamensis complex. Journal of Herpetology 23: 50-60.

Pough, F.H., R.M. Andrews, J.E. Cadle, M.L. Crump, A.H. Savitzky \& K.D. Wells (2000). Herpetology - 2nd Edition. Prentice-Hall, Upper Saddle River, New Jersey, 612pp.

Rao, K.T., Ghate, H.V., Sudhakar, A.M., Javed, S.M.M. \& I.S.R. Krishna (2005). Herpetofauna of Nallamalai Hills with eleven new records for the region including ten new records for Andhra Pradesh. Zoos' Print Journal 20(1): 1737-1740+web supplement.

Rao, S.K. \& N.V. Aswathanarayana (1979). Karyological studies on four species of lizards from peninsular India. Current Science 48(15): 667-671.

Rooij, N.de. (1915). The Reptiles of the Indo-Australian Archipelago. I. Lacertilia, Chelonia, Emydosauria. Leiden (E. J. Brill), Netherlands, xiv+384pp.

Russell, A.P. (1977). The phalangeal formula of Hemidactylus Oken, 1817 (Reptilia: Gekkonidae): a correction and a functional explanation. Journal of Veterinary Medicine $C$. Anatomia, Histologia, Embryologia 6: 332-338.

Sharma, R.C. (1981). Hemidactylus porbandarensis, a new geckonid lizard from Gujarat, India. Bulletin of the Zoological Survey of India 4(1): 1-2.

Sharma, R.C. (2002). Fauna of India, Reptilia, Vol. II, Sauria. Zoological Survey of India, Calcutta, 430pp.

Shukla, V.N. (1983). A new species of the lizard Hemidactylus from Kanpur, India. Indian Journal of Zootomy 24: 81-83.

Smith, M.A. (1935). Fauna of British India including Ceylon and Burma. Reptilia and Amphibia, Volume II, Sauria. Today and Tomorrow's Printers \& Publishers, New Delhi, Indian Reprint 
1974, 440pp.

Srinivasulu, C. \& I. Das (2008). The herpetofauna of Nallamala Hills, Eastern Ghats, India: An annotated checklist, with remarks on nomenclature, taxonomy, habitat use, adaptive types and biogeography. Asiatic Herpetological Research 11: 110-131.

Uetz, P. (2010). The Institute of Genomic Research, now the J Craig Venter Institute (JCVI). Website: <http://www.jcvi.org/reptiles/species.php? > (Accessed on $7^{\text {th }}$ January 2010).

Vences, M., S. Wanke, D.R. Vieites, B. Branch \& F. Glaw (2004). Natural colonisation or introduction? High genetic divergences and phylogeographic relationships of house geckos (Hemidactylus) from Madagascar. Biological Journal of the Linnean Society 83: 115-130.

Vyas, R., V. Giri \& A.M. Bauer (2006). First record of Hemidactylus persicus Anderson, 1872 (Squamata: Sauria: Gekkonidae) from the Republic of India, with notes on its distribution. Hamadryad 30(1-2): 209-211.

Wells, R.W. (2002). Notes on the genus Hemidactylus (Reptilia: Gekkonidae) in Australia. Australian Biodiversity Record (6): 1-8.

Wells, R.W. \& C.R. Wellington (1985). A classification of the Amphibia and Reptilia in Australia. Australian Journal of Herpetology (Supplementary Series) 1: 1-61.

Zug, G.R., J.V. Vindum \& M.S. Koo (2007). Burmese Hemidactylus (Reptilia, Squamata, Gekkonidae): taxonomic notes on tropical Asian Hemidactylus. Proceedings of the California Academy of Sciences, Fourth Series 58: 387-405.

\section{Material compared}

Hemidactylus frenatus. Andhra Pradesh: ZSIK-24225 (08.ix.1984, D.P.

Sanyal, Kaleswar locality, Kareemnagar District), ZSIK -24648 \& 24652 (21 \& 23.i.1988, D.P. Sanyal, Kothakota locality, Mehaboobnagar District), ZSIK23586 (22.ii.1978, A.P. Survey, Kotpalli locality, Adilabad District), ZSIK-23700 (15.ii.1979, A.P. Survey, Macharam locality, Mehaboobnagar District); Assam: ZSIK-24334 (29.iii.1986, S.S. Saha, Manus Tiger Reserve, Kamrup District); Bihar: ZSIK-24449 (14.iv.1986, S. Ahamad, Manihari locality, Katihar District); Karnataka: ZSIK-22658 (14.ix.1973, A. Laxminarayana, Mysore District); Orissa: ZSIK-22958 (14.xi.1971, D.P. Sanyal, Gopalpur locality, Gunjam District); West Bengal: ZSIK-24128 (29.iii.1984, S.S. Saha, Tantipara, Birbhum District).
Author Details: Mr. S.M. MAQSOOD JAVED is a Senior Field Researcher cum Education Officer. His interest lies in biodiversity studies with special emphasis on arachnofauna and herpetofauna

Dr. C. SRinivasulu is Assistant Professor in Department of Zoology. He is the head of the research laboratory at Osmania University that focuses on biodiversity inventorying, conservation, ecology and animal taxonomy with special reference to Eastern Ghats and Godavari River basin in Andhra Pradesh.

DR. K. LAKSHMI RAO is working as a Scientist. She has been associated with Chromosomal diagnostics services. Her group research activities focus on reproductive disorders. She has established primary cell lines from reptiles especially from various Indian snakes and crocodiles which were subsequently characterized cytogenetically.

Ms. T. RASESWARI is a Technical Assistant, under Dr. K. Lakshmi Rao and works on cytogenetics. Ms. FARIDA TAMPAL is State Director of the Andhra Pradesh State Office of World Wide Fund for Nature - India. She is interested in understanding the biodiversity of the Eastern Ghats with special emphasis on arachnofauna and herpetofauna.

Acknowledgements: The authors are very much thankful to Shri Hitesh Malhotra, IFS, Principal Chief Conservator of Forest (Wildlife) and Chief Wildlife Warden, Andhra Pradesh, Dr. R. Hampaiah, Chairman and Dr. V.B. Ramana Murthy, Member Secretary, Andhra Pradesh Biodiversity Board for constant support and encouragement. SMMJ and FT express gratitude to Shri Anil Kumar V. Epur, Chairman, WWF-AP State Committee, Hyderabad and Shri Ravi Singh, Secretary General \& CEO, WWF-India, New Delhi for constant support and encouragement. We express our thanks to Shri Swaranjit Sen, IPS (Retd.), Chairman, Shri B. Venkatesham, IAS, Managing Director and Shri P.V. Ramana Reddy, IFS, Executive Director, Andhra Pradesh Tourism Development Corporation, Hyderabad for constant support and permitting us to conduct biodiversity studies in APTDC Eco-tourism sites. CS thanks Prof. T. Tirupathi Rao, Vice Chancellor, Osmania University and the Head, Department of Zoology, Osmania University, Hyderabad for encouragement and facilities. We are thankful to Dr. Lalji Singh for helping us to use the karyotyping facility in CCMB, Hyderabad. We are very much thankful to Dr. Hidetoshi Ota, Dr. George Zug, Mr. Varad Giri, Mr. Stephen Mahony, Mr. Zeeshan A Mirza for reviewing the first draft of manuscript, constructive suggestions and sharing literature. Dr. Bhargavi Srinivasulu, Mr. R. Sreekar, Mr. M. Seetharamaruju and Ms. Harpreet Kaur of Department of Zoology, Osmania University assisted in taking morphological and morphometric data. Lastly, we would like to thank Mr. P.S.M. Srinivas, Manager Corporate for exploring new places and all the WWF-Staff of APSO, Hyderabad for their constant support and timely suggestions. 